\title{
SUPPRESSION OF URIC ACID SYNTHESIS IN THE GOUTY HUMAN BY THE USE OF 6-DIAZO-5-OXO-L- NORLEUCINE *
}

\author{
By ARTHUR I. GRAYZEL, J. E. SEEGMILLER ANd ETHEL LOVE \\ (From the National Institute of Arthritis and Metabolic Diseases, National Institutes of \\ Health, Bethesda, Md.)
}

(Submitted for publication September 23, 1959; accepted October 30, 1959)

\begin{abstract}
A substantial number of patients with gout has been shown to produce excessive amounts of uric acid (1-4). This overproduction has been demonstrated by the excretion of greater than normal amounts of uric acid in the urine, or an excessive incorporation of isotopically labeled glycine into urinary uric acid. The present day treatment of tophaceous gout consists primarily in the administration of uricosuric agents to increase the renal excretion of the uric acid formed, with use of colchicine, ACTH gel, or phenylbutazone for management of the acute attacks. Control of the production of uric acid has been of necessity confined to limiting the purine and protein. content of the diet (5).
\end{abstract}

A logical approach to the treatment of those patients who overproduce uric acid would be to inhibit the excessive production by pharmacologic agents. In recent years several compounds have been reported to interfere with purine biosynthesis. Two such compounds, azaserine (o-diazoacetyl-L-serine) and 6-diazo-5-oxo-L-norleucine (DON), have been shown to suppress the formation of purines in bacteria (6), and Krakoff and Karnofsky have shown that DON inhibits uric acid production in the pigeon (7). Both compounds are structural analogs of glutamine (see Figure 1) and both have been used in the human as potential chemotherapeutic agents against cancer $(8,9)$. Using partially purified enzyme systems, Levenberg, Melnick and Buchanan (10) demonstrated that these agents do indeed prevent the synthesis of inosinic acid by blocking the utilization of glutamine in the enzymatic conversion of formylglycinamide ribotide to formylglycinamidine ribotide (Figure 2). DON was found to be the more potent inhibitor of the enzyme system, requiring only 0.025 the concentra-

* A preliminary report of this work has been published in abstract form (J. clin. Invest. 1959, 38, 1008). tion of azaserine to obtain the same degree of inhibition. Although glutamine is also required in the first step in purine biosynthesis, these agents are less effective inhibitors of this earlier reaction. Zuckerman, Drell and Levin (11) have shown that azaserine reduced the incorporation of glycine-1- $\mathrm{C}^{14}$ into urinary uric acid in gouty humans, but did not alter either the serum urate levels or the urinary excretion of uric acid. The purpose of our study was to observe the effect of the administration of DON on uric acid production in gouty patients, as measured by changes in the serum urate levels and urinary excretion of uric acid, and by the incorporation of glycine-1- $\mathrm{C}^{14}$ into urinary uric acid.

\section{METHODS}

Six male patients with gout and one with urate renal lithiasis and essential hyperuricemia were studied during hospitalization. They were all maintained on a standard 2,600 calorie, $70 \mathrm{~g}$ protein diet, essentially free of purines.
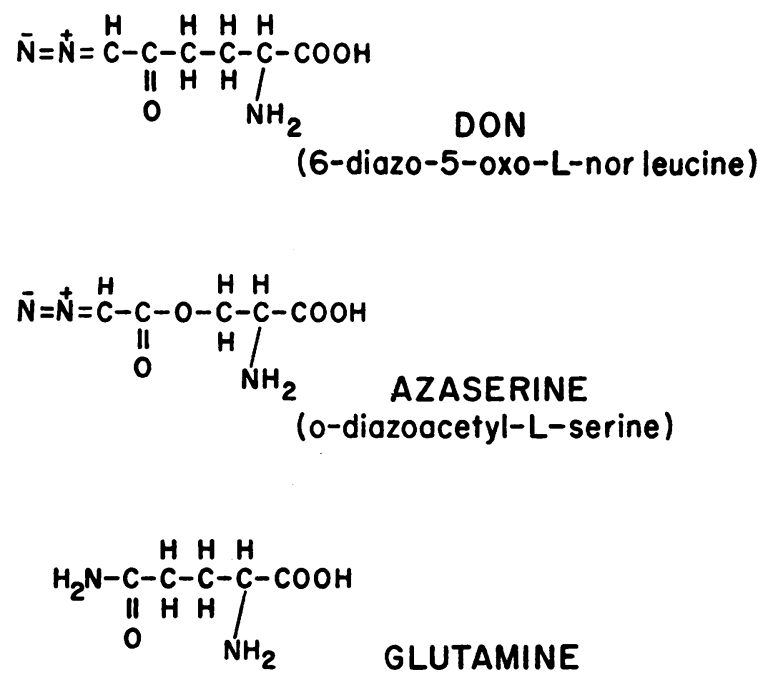

Fig. 1. DON, AZASERINe and glutamine, Showing STRUCTURAL RELATIONSHIPS. 

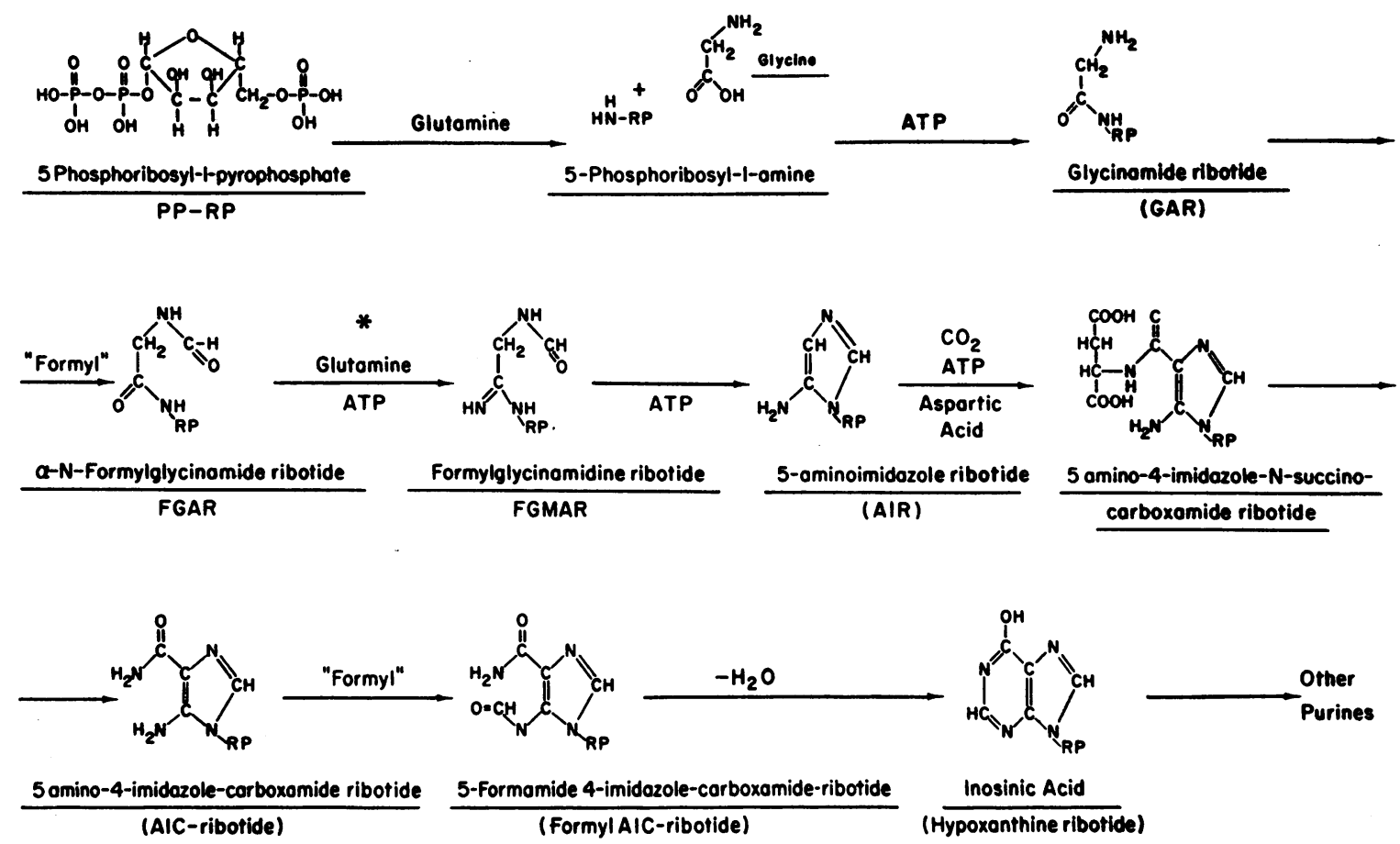

Fig. 2. Pathway for The biosynthesis of URIC ACID. Asterisk indicates the enzyme that is inhibited by DON.

At least five days were allowed for equilibration before studies were begun. Daily 24 hour urine collections were preserved with toluene at room temperature. The uric acid determinations of both urine and serum were made by means of an enzymatic spectrophotometric assay (12). Urinary creatinine was determined by the method of Taussky (13). DON provided by the Cancer Chemo- therapy National Service Center was freshly made up in solution at the beginning of each study and stored in the frozen state. It was given by the intramuscular route, either $10 \mathrm{mg}$ daily or in divided doses of 2.5 or 5 mg every six hours. Isotopically labeled compounds were administered on the third day of DON therapy immediately following DON injection. Glycine-1-C ${ }^{14}$ (obtained

TABLE I

Serum urate levels and 24 hour urinary uric acid excretion in patients receiving 6-diazo-5-oxo-L-norleucine (DON)

\begin{tabular}{|c|c|c|c|c|c|c|c|}
\hline \multirow[b]{3}{*}{ Patient } & \multirow[b]{3}{*}{ Age } & \multirow[b]{3}{*}{ Diagnosis } & \multirow[b]{3}{*}{$\begin{array}{c}\text { Dose of DON } \\
\text { per day }\end{array}$} & \multicolumn{2}{|c|}{ Serum urate } & & \\
\hline & & & & \multirow{2}{*}{$\begin{array}{l}\text { Average of } 2 \\
\text { days prior to } \\
\text { administra- } \\
\text { tion of } \\
\text { DON }\end{array}$} & \multirow[b]{2}{*}{$\begin{array}{c}\text { Lowest } \\
\text { while } \\
\text { receiving } \\
\text { DON }\end{array}$} & \multicolumn{2}{|c|}{ Excretion of uric acid } \\
\hline & & & & & & $\begin{array}{c}\text { Before DON } \\
\text { (average of } \\
3 \text { days) }\end{array}$ & $\begin{array}{l}\text { Lowest while } \\
\text { receiving } \\
\text { DON }\end{array}$ \\
\hline T. B. & $\begin{array}{l}y r s \\
39\end{array}$ & $\begin{array}{l}\text { Essential } \\
\text { hyperuricemia } \\
\text { and renal urate } \\
\text { lithiasis }\end{array}$ & $10 \mathrm{mg}$ & $\begin{array}{c}m g / 100 m l \\
9.5\end{array}$ & $\begin{array}{c}m g / 100 m l \\
6.5\end{array}$ & $\begin{array}{c}m g / 24 \mathrm{hr} \\
1,280\end{array}$ & $\begin{array}{c}m g / 24 \mathrm{hr} \\
730\end{array}$ \\
\hline S. $M$. & 53 & Tophaceous gout & $10 \mathrm{mg}$ & 9.4 & 9.9 & 393 & 313 \\
\hline R. J. & 41 & Tophaceous gout & $\begin{array}{c}20 \mathrm{mg} \\
\text { in divided } \\
\text { doses }\end{array}$ & 10.2 & 9.0 & 1,140 & 716 \\
\hline F. J. & 34 & Tophaceous gout & $5 \mathrm{mg}$ & 10.9 & 11.4 & 1,250 & 1,110 \\
\hline N. M. & 49 & Gout & $5 \mathrm{mg}$ & 10.6 & 9.7 & 570 & 408 \\
\hline J. S. & 53 & Gout & $10 \mathrm{mg}$ & 7.9 & 7.5 & 598 & 467 \\
\hline A. $\mathrm{H}$. & 48 & Tophaceous gout & $10 \mathrm{mg}$ & 7.5 & 6.9 & 494 & 417 \\
\hline
\end{tabular}



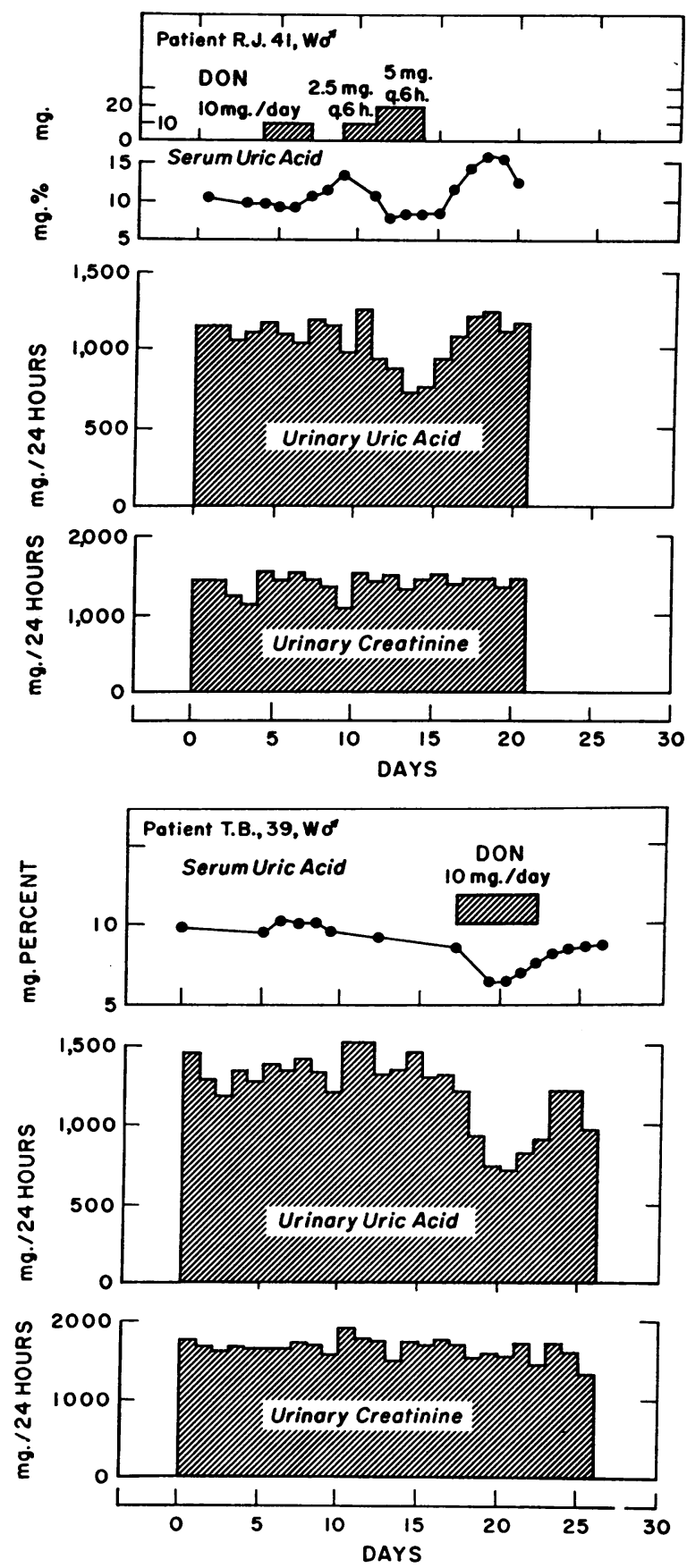

Fig. 3. THE EFFECT OF DON ON SERUM URATE LEVELS AND URINARY URIC ACID EXCRETION.

from Tracerlab Company of Boston), with a specific activity of $1.33 \mathrm{mc}$ per mmole, was given orally in a dose of $5 \mu \mathrm{c}$ with the breakfast milk. Simultaneously, $36 \mathrm{mg}$ of uric acid $\mathrm{N}^{15}$, containing 28.6 atom per cent excess of $\mathrm{N}^{15}$, was administered intravenously as the lithium salt to measure the urate pool and to allow corrections to be made for altered dynamics of this pool (14).1 The glycine pool, contributing to hippuric acid, was sampled by administering $450 \mathrm{mg}$ of sodium benzoate intravenously, collecting urine for a two hour period immediately following the injection, and isolating hippuric acid from the specimen. Such sampling was done six hours after the initial administration of glycine-1- $\mathrm{C}^{14}$ and during the first two hours of the collection period on the succeeding second, third, fifth and seventh days. A period of at least three months was allowed between control and DON studies to allow for elimination of most of the $\mathrm{C}^{14}$ and correction was made for residual $\mathrm{C}^{14}$. Hippuric acid was isolated by extraction with ether and recrystallization from hot water (15). Urinary creatinine, as the double zinc salt (16), was isolated from urine. Uric acid was isolated from aliquots of urine by adsorption on activated charcoal (17), or by preliminary precipitation as a copper salt when urine volumes exceeded $1,500 \mathrm{ml}$ per day (18). Radioactivity was determined using an end-window gas flow counter (Nuclear, Chicago) from planchets plated at infinite thickness with sufficient time for counting to produce an error of not more than 3 per cent. The $\mathrm{N}^{15}$ content of uric acid was determined in a Consolidated-Nier mass spectrometer following preliminary digestion (19).

\section{RESULTS}

The effect of the administration of DON on the serum urate levels, and on the 24-hour urinary uric acid excretion values in the two patients who demonstrated the greatest response to DON, are shown in Figure 3. The results obtained in all patients are presented in Table I. Even though the data in this table are presented in a manner that would emphasize small differences, i.e., by comparing the average of several days during the pretreatment period with the lowest values obtained during treatment, the differences are not great. In four patients the difference in urinary uric acid excretion was of the order of 20 per cent. Two patients showed a slight increase in serum urate levels during DON therapy. These two patients both had tophaceous gout and the increased miscible urate pool may have prevented the decline of their serum urate levels and urinary uric acid excretion which might otherwise have resulted from a decrease in urate production.

A more sensitive index of purine biosynthesis is provided by the incorporation of glycine-1- $\mathrm{C}^{14}$

\footnotetext{
1 We are indebted to Miss Jean Benedict for providing the uric acid-1,3-N $\mathrm{N}^{15}$.
} 

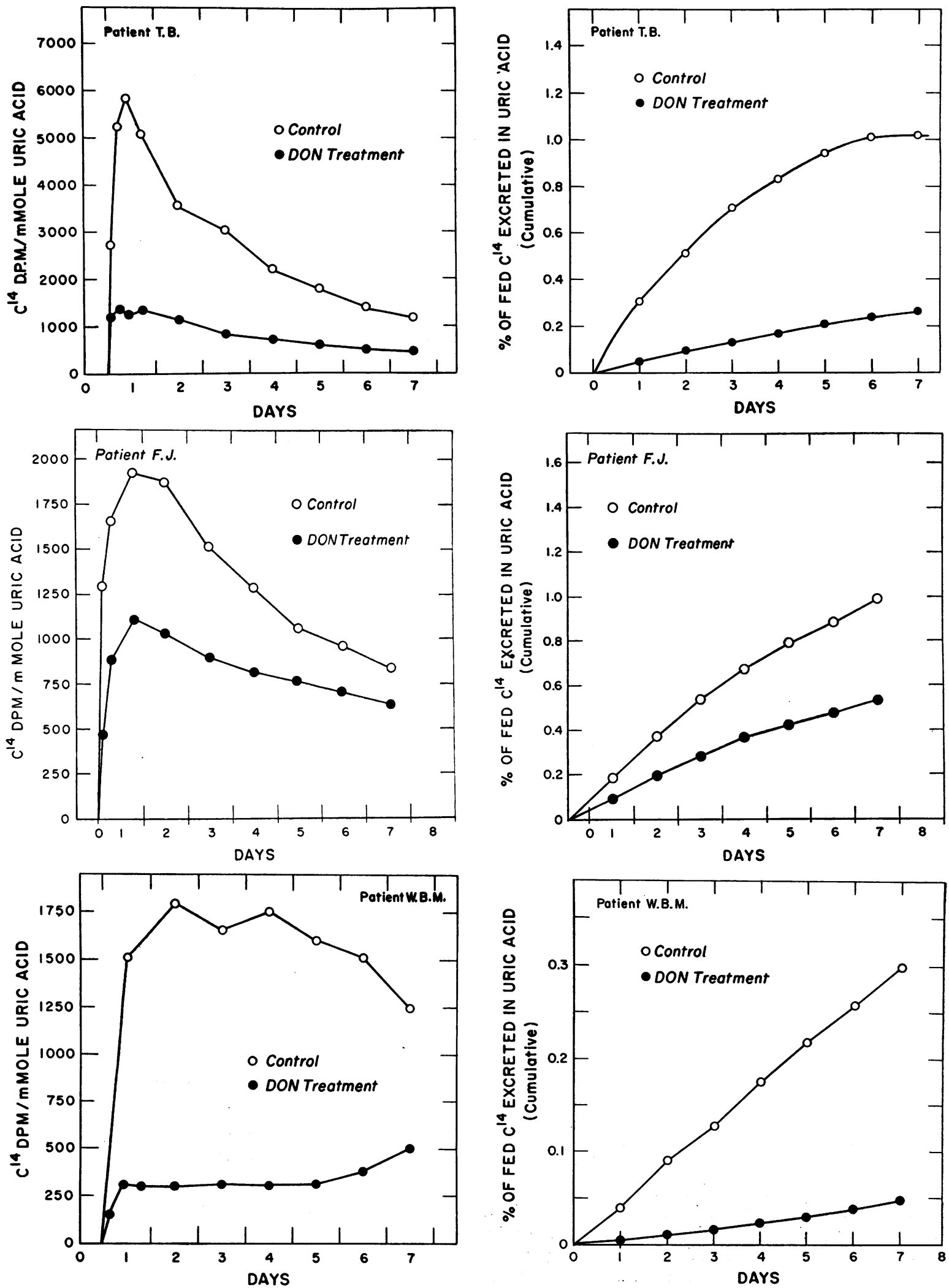

Fig. 4. THE EFFECT OF DON ON THE SPECIFIC ACTIVITY, IN DISINTEGRATIONS PER MINUTE PER MILLIMOLE OF URINARY URIC ACID, RESULTING FROM THE ORAL ADMINISTRATION OF $5 \mu \mathrm{C}$ OF GLYCINE-1-C $\mathrm{C}^{\mathbf{4}}$.

Fig. 5. The effect of DON ON The cumulative INCORPORATION OF GLYCINE-1-C ${ }^{14}$ INTO URINARY URIC ACID. All values are normalized to the same dose of administered glycine-1- $\mathrm{C}^{\mathbf{1 4}}$. 
TABLE II

Suppression of uric acid synthesis from glycine-1-C $C^{14}$ by $D O N$

\begin{tabular}{|c|c|c|c|c|c|c|c|}
\hline \multirow[b]{4}{*}{ Patient } & \multicolumn{6}{|c|}{ Per cent recovery of administered isotope in urinary uric acid in 7 days } & \multirow{4}{*}{$\begin{array}{c}\text { Effect of } \\
\text { DON } \\
\text { Per cent } \\
\text { of control } \\
\text { incorporation }\end{array}$} \\
\hline & \multirow{2}{*}{\multicolumn{2}{|c|}{$\frac{\text { Glycine-1-C }}{\text { (a) }}$}} & \multicolumn{2}{|c|}{ Uric acid $\mathrm{N}^{15}$} & \multicolumn{2}{|c|}{$\begin{array}{l}C^{14} \text { corrected for } \\
\text { recovery of } N^{15}\end{array}$} & \\
\hline & & & & & (a) & & \\
\hline & Control & DON & Control & DON & Control & DON & \\
\hline $\begin{array}{l}\text { T. B. } \\
\text { F. J. } \\
\text { W. M. }\end{array}$ & $\begin{array}{l}1.11 \\
0.99 \\
0.30\end{array}$ & $\begin{array}{l}0.26 \\
0.61 \\
0.05\end{array}$ & $\begin{array}{c}77.2 \\
80.6\end{array}$ & $\begin{array}{l}75.2 \\
72.8 \\
35.7\end{array}$ & $\begin{array}{l}1.44 \\
1.23\end{array}$ & $\begin{array}{l}0.35 \\
0.84\end{array}$ & $\begin{array}{l}24 \\
68 \\
17\end{array}$ \\
\hline
\end{tabular}

* No $\mathrm{N}^{15}$ urate administered.

into urinary uric acid. Figure 4 shows the effect of DON therapy on the specific activity of $\mathrm{C}^{14}$ in urinary uric acid; Figure 5 shows the cumulative incorporation of $\mathrm{C}^{14}$ into urinary uric acid in three patients. From Table II it is apparent that Patients W. M. and F. J., who failed to show a decline in serum urate during therapy, nevertheless showed a substantially decreased incorporation of glycine-1-C $\mathrm{C}^{14}$ into uric acid indicative of a depressed purine biosynthesis accompanying DON therapy.

In two of these patients corrections were made for the dynamics of the urate pool, as evidenced

TABLE III

Toxic manifestations in patients receiving DON

\begin{tabular}{|c|c|c|c|}
\hline Patient & $\begin{array}{l}\text { Dose of } \\
\text { DON }\end{array}$ & $\begin{array}{l}\text { Dura- } \\
\text { tion }\end{array}$ & Toxic manifestations \\
\hline & $m g / d a y$ & days & \\
\hline T. B. & 10 & 5 & $\begin{array}{l}\text { Erosions of oral mucosa on day } 5 \\
\text { of therapy }\end{array}$ \\
\hline W. M. & 10 & 5 & $\begin{array}{l}\text { Erosions of oral mucosa on day } 5 \\
\text { of therapy }\end{array}$ \\
\hline \multirow[t]{2}{*}{ R. J. } & 10 & 5 & $\begin{array}{l}\text { Erosions of oral mucosa on day } 3 \\
\text { of higher dose }\end{array}$ \\
\hline & 20 & 3 & $\begin{array}{l}\text { Asymptomatic duodenal ulcer dem- } \\
\text { onstrated by X-ray } \\
\text { (Films taken at another hospital } 2 \\
\text { months previously showed a de- } \\
\text { formed duodenum) }\end{array}$ \\
\hline F. J. & 5 & 5 & None \\
\hline \multirow[t]{2}{*}{ N. M. } & 5 & 9 & $\begin{array}{l}\text { Erosions of oral mucosa on day } 5 \\
\text { of higher dose }\end{array}$ \\
\hline & 10 & 6 & $\begin{array}{l}\text { Asymptomatic duodenal ulcer dem- } \\
\text { onstrated on X-ray }\end{array}$ \\
\hline J. S. & 10 & 6 & $\begin{array}{l}\text { Erosions of oral mucosa on day } 6 \\
\text { Negative upper GI X-ray }\end{array}$ \\
\hline A. $\mathrm{H}$. & 10 & 6 & $\begin{array}{l}\text { Shallow erosion of tip of tongue on } \\
\text { day } 6 \\
\text { Negative upper GI X-ray }\end{array}$ \\
\hline
\end{tabular}

by the recovery of injected uric acid $\mathrm{N}^{15}$ in urinary uric acid (Table II). By seven days the enrichment of urinary uric acid with $\mathrm{N}^{15}$ in each study had declined in a logarithmic manner to values approximating 1.0 per cent of those observed on the first day, except in Patient W. M., in whom the value was 5 per cent. The fraction of $\mathrm{N}^{15}$ not recovered in urinary uric acid represents urate removed from the body pool by means other than renal excretion. These would include deposition in tophi, losses via perspiration and gastrointestinal uricolysis. Thus, an estimation can be made of the amount of $\mathrm{C}^{14}$ actually delivered to the body's urate pool which did not appear as urinary uric acid. Such a corrected figure represents the best approximation of the extent of purine synthesis de novo. In Patient T. B., who received $10 \mathrm{mg}$ of DON per day, the corrected cumulative incorporation was reduced to 24 per cent of the control value. In Patient F. J., $5 \mathrm{mg}$ of DON per day resulted in a reduction to 68 per cent of the control value. The specific activity of the glycine pools sampled by hippuric acid and by creatinine was not significantly altered following DON administration.

The toxic effects consisting of a sore mouth, occasionally with evidence of shallow erosions of the mucous membrane of the under lip, were observed at the end of five days in five patients (Table III). Two patients who received DON for 14 and 7 days, respectively, developed asymptomatic duodenal ulcers which healed promptly on medical therapy once the DON was stopped. One patient, F. J., had no symptoms on a dose of $5 \mathrm{mg}$ per day, although there was an effect on his incorporation of glycine into urinary uric 
acid. No depression of the formed elements of the blood, changes in liver function, including the serum glutamic-oxalacetic transaminase level, abnormalities of the urinary sediment, or occult blood in the stools were noted.

\section{DISCUSSION}

DON had a marked effect on purine biosynthesis in the human, as shown by a substantial reduction in the incorporation of glycine-1- $\mathrm{C}^{14}$ into urinary uric acid in all three patients studied. Such findings are consistent with the interpretation that DON exerts an effect in vivo in the human similar to the effect observed in other biological systems. Presumably, such effects result from its action in blocking the enzymatic conversion of formylglycinamide ribotide to formylglycinamidine ribotide. That DON has an effect on other glutamine-requiring reactions (20) leaves open the possibility that other, more specific inhibitors of purine biosynthesis may be found having fewer undesirable side effects.

DON administration failed to affect significantly the specific activity of the glycine pool sampled by hippuric acid and by creatinine. This is evidence that absorption of glycine-1-C ${ }^{14}$ from the intestine was unaffected by DON, and further supports the view that the action of DON, in the dosage used in this study, is primarily a suppression of purine synthesis. The failure of balance studies to demonstrate a marked reduction in serum urate levels or urinary uric acid excretion in five of the seven patients studied has several possible explanations. With the short periods of drug administration and the presence of a large miscible urate pool, a balance study may fail to reflect brief changes in uric acid synthesis because of the dampening effect of such a pool. The failure to obtain any decrease in serum urate levels in Patients R. J. and W. N., despite a substantial suppression of purine biosynthesis, as shown by reduced glycine incorporation, might be explained by the fact that these two patients had the largest tophaceous deposits of all the patients studied. Another possible explanation may be related to the relatively short half-life of DON in the blood (approximately three to four hours following its intramuscular administration) (9).
Thus, maximal effects of DON were obtained at a time when glycine-1- $\mathrm{C}^{14}$ in the body had its highest specific activity. A compensatory overproduction of uric acid during the remainder of the day may have masked such a suppression at a gross level.

Upon discontinuing DON therapy, the serum urate showed a rebound, similar to that shown in Figure 3 (Patient R. J.), to values higher than those of the control period in five of the seven patients studied. Such transient elevations may well be related to the operation of a homeostatic control of purine synthesis $(21,22)$ similar to that described for pyrimidine synthesis in bacteria (23). A derangement of such homeostatic control can be produced by the drug 2-ethylamino1,3,4-thiadiazole $(24,25)$. A constitutional derangement in such a controlling mechanism has been proposed to account for the increased uric acid synthesis seen in some cases of gout. A suppression of purine biosynthesis has also been produced by administering 4-amino-5-imidazolecarboxamide (21). This substance, however, is itself converted to uric acid and so is of no value in treatment of the excessive production of uric acid seen in gout.

A considerable variability in responsiveness of different patients to a given dose of DON makes evaluation of its therapeutic index difficult. DON given for five days at a dose of $5 \mathrm{mg}$ per day to Patient F. J. had no untoward side effects. The same dose continued for nine days in the second patient, N. M., again produced no untoward side effects, but when the dose was increased to $10 \mathrm{mg}$ per day, an asymptomatic duodenal ulcer developed after five days. Although DON administered in higher doses as chemotherapy for cancer results in a significant incidence of leukopenia, thrombocytopenia, nausea and vomiting (9), no such toxic effects were observed during this study. The relatively high incidence of oral toxicity and peptic ulceration, even at relatively low doses, makes the use of DON imprudent in managing patients who overproduce uric acid. This approach, however, of reducing excessive uric acid production by means of inhibitors of purine biosynthesis appears to be possible, and warrants a further search for a more specific inhibitor with a more favorable therapeutic index. 


\section{SUMMARY}

DON (6-diazo-5-oxo-L-norleucine) has been administered to six gouty patients and to one pation with renal urate lithiasis and essential hyperuricemia. 1) Studies performed on three patients demonstrated that DON suppressed the incorporation of glycine-1-C $\mathrm{C}^{14}$ into urinary uric acid. 2) Balance studies demonstrated that in two patients there was a significant decrease in serum urate levels and 24-hour urinary uric acid excretion following the administration of DON. 3) From the above studies, it is concluded that DON suppresses uric acid biosynthesis, but such suppression is not always reflected in a short-term balance study, especially in the presence of an expanded urate pool. 4) The use of pharmacologic agents to suppress synthesis in those gouty patients who overproduce uric acid represents a new and rational approach to their therapy. The high incidence of side effects following DON administration prevents the practical use of this particular drug.

\section{ACKNOWLEDGMENT}

The authors wish to express their appreciation to Mrs. Dolores Anderson and Miss Emma Lou Hendrickson for technical assistance, and to Mr. William Comstock for the $\mathrm{N}^{15}$ determinations.

\section{REFERENCES}

1. Benedict, J. D., Roche, M., Yü, T. F., Bien, E. J., Gutman, A. B., and Stetten, DeW., Jr. Incorporation of glycine nitrogen into uric acid in normal and gouty man. Metabolism 1952, 1, 3.

2. Wyngaarden, J. B. Overproduction of uric acid as the cause of hyperuricemia in primary gout. J. clin. Invest. 1957, 36, 1508.

3. Seegmiller, J. E., Laster, L., and Liddle, L. V: Failure to detect consistent overincorporation of glycine-1-C $\mathrm{C}^{\mathbf{1 4}}$ into uric acid in primary gout. Metabolism 1958, 7, 376.

4. Gutman, A. B., Yü, T. F., Black, H., Yalow, R. S., and Berson, S. A. Incorporation of glycine-1- $\mathrm{C}^{14}$, glycine-2- $\mathrm{C}^{14}$, and glycine- $\mathrm{N}^{15}$ into uric acid in normal and gouty subjects. Amer. J. Med. 1958, 25, 917.

5. Bien, E. J., Yü, T. F., Benedict, J. D., Gutman, A. B., and Stetten, DeW., Jr. The relation of dietary nitrogen consumption to the rate of uric acid synthesis in normal and gouty man. J. clin. Invest. 1953, 32, 778 .

6. Maxwell, R. E., and Nickel, V. S. 6-Diazo-5-oxo-Lnorleucine, a new tumor-inhibitory substance. $\mathrm{V}$.
Microbiologic studies of mode of action. Antibiot. and Chemother. 1957, 7, 81.

7. Krakoff, I. H., and Karnofsky, D. A. Inhibition of uric acid biosynthesis in birds by 0 -diazoacetyl-Lserine (azaserine) and 6-diazo-5-oxo-L-norleucine (DON). Amer. J. Physiol. 1958, 195, 244.

8. Ellison, R. R., Karnofsky, D. A., Sternberg, S. S., Murphy, M. L., and Burchenal, J. H. Clinical trials of $o$-diazoacetyl-L-serine (azaserine) in neoplastic disease. Cancer 1954, 7, 801.

9. Magil, G. B., Myers, W. P. L., Reilly, H. C., Putnam, R. C., Magil, J. W., Sykes, M. P., Escher, G. C., Karnofsky, D. A., and Burchenal, J. H. Pharmacologic and initial therapeutic observations on 6-diazo-5-oxo-L-norleucine (DON) in human neoplastic disease. Cancer 1957, 10, 1138.

10. Levenberg, B., Melnick, I., and Buchanan, J. M. Biosynthesis of the purines. XV. The effect of aza-L-serine and 6-diazo-5-ox@-L-norleucine on inosinic acid biosynthesis de novo. J. biol. Chem. 1957, 225, 163.

11. Zuckerman, R., Drell, W., and Levin, M. H. The effect of azaserine on the incorporation of glycine- $\mathrm{C}^{\text {14 }}$ into uric acid in the gouty human (abstract). Ninth International Congress on Rheumatic Diseases, Toronto, 1957, vol. II, p. 204.

12. Liddle, L., Seegmiller, J. E., and Laster, L. The enzymatic spectrophotometric method for determination of uric acid. J. Lab. clin. Med. 1959, 54, 903.

13. Taussky, H. H. A microcolorimetric determination of creatine in urine by the Jaffé reaction. J. biol. Chem. 1954, 208, 853.

14. Benedict, J. D., Forsham, P. H., and Stetten, DeW., Jr. The metabolism of uric acid in the normal and gouty human studied with the aid of isotopic uric acid. J. biol. Chem. 1949, 181, 183.

15. Soloway, S., and Stetten, DeW., Jr. The metabolism of choline and its conversion to glycine in the rat. J. biol. Chem. 1953, 204, 207.

16. Benedict, S. R. Studies in creatine and creatinine metabolism. I. The preparation of creatine and creatinine from urine. J. biol. Chem. 1914, 18, 183.

17. Geren, W., Bendich, A., Bodansky, O., and Brown, G. B. The fate of uric acid in man. J. biol. Chem. 1950, 183, 21.

18. Hawk, P. B., Oser, B. L., and Summerson, W. H. Practical Physiological Chemistry, 13th ed. New York, McGraw-Hill Book Company, 1954, p. 911.

19. Rittenberg, D. The preparation of gas samples for mass spectrographic isotope analysis in Preparation and Measurement of Isotopic Tracers, D. W. Wilson, A. O. C. Nier and S. P. Reimann, Eds. Ann Arbor, Edward Brothers, 1946, p. 31.

20. Eidinoff, M. L., Knoll, J. E., Marano, B., and Cheong, L. Pyrimidine studies. I. Effect of DON (6-diazo-5-oxo-L-norleucine) on incorporation of pre- 
cursors into nucleic acid pyrimidines. Cancer Res. 1958, 18, 105.

21. Seegmiller, J. E., Laster, L., and Stetten, DeW., Jr. Incorporation of 4-amino-5-imidazolecarboxamide$4-\mathrm{C}^{13}$ into uric acid in the normal human. J. biol. Chem. 1955, 216, 653.

22. Wyngaarden, J. B., and Ashton, D. M. The regulation of activity of phosphoribosylpyrophosphate amidotransferase by purine ribonucleotides: A potential feedback control of purine biosynthesis. J. biol. Chem. 1959, 234, 1492.
23. Yates, R. A., and Pardee, A. B. Control of pyrimidine biosynthesis in Escherichia coli by a feed-back mechanism. J. biol. Chem. 1956, 221, 757.

24. Seegmiller, J. E., Grayzel, A. I., and Liddle, L. Excessive uric acid production in the human induced by 2-ethylamino-1,3,4-thiadiazole. Nature (Lond.) 1959, 183, 1463.

25. Krakoff, I. H., and Balis, M. E. Studies on the uricogenic effect of 2-substituted thiadiazoles in man. J. clin. Invest. 1959, 38, 907.

\section{ANNOUNCEMENT OF MEETINGS}

The Fifty-Second Annual Meeting of THE AMERICAN SOCIETY FOR CLINICAL INVESTIGATION will be held in Atlantic City, N. J., on Sunday afternoon and evening, May 1, 1960, in the Chalfonte-Haddon Hall (jointly with the AFCR) ; and on Monday, May 2, at 9:00 A.M., at the Casino Theater on the Steel Pier.

The Seventeenth Annual Meeting of THE AMERICAN FEDERATION FOR CLINICAL RESEARCH will be held in Atlantic City, N. J., on Sunday, May 1, 1960, at 9:00 A.M., at the Casino Theater on the Steel Pier. On Sunday afternoon and evening, May 1, 1960, a joint sectional meeting with The American Society for Clinical Investigation will be held in rooms in the Chalfonte-Haddon Hall.

THE ASSOCIATION OF AMERICAN PHYSICIANS will hold its Seventy-Third Annual Meeting in Atlantic City, N. J., at the Casino Theater on the Steel Pier on Tuesday, May 3, 1960, at 9:30 A.M., and in the Vernon Room, Chalfonte-Haddon Hall, on Wednesday, May 4, 1960, at 9:30 A.M. 